\title{
The Stability of Constitutions and Their Role in Promoting Intergenerational Justice
}

\author{
Fruzsina Gárdos-Orosz* \\ UDK $\quad 342.4:: 342.565 .2$ \\ 342.4:340.114-053 \\ Preliminary scientific report / prethodno znanstveno priopćenje \\ Received/primljeno: 20. 9.2017. \\ Accepted / prihvaćeno: 22.12.2017.
}

Do constitutions serve intergenerational justice? The paper proposes that constitutionalism should be understood as a purely legal concept in order to explore satisfactory answers to questions regarding how and whether a constitution helps to promote intergenerational justice. I argue that the normative approach can explain that constitutions are effective means of approaching (as opposed to hindering) intergenerational justice. The binding nature of the constitution, especially of some unamendable provisions, is already justified in doctrine as an essential element of all normative orders. I argue that this boundary nature is not a hindrance, but rather a helpful reference point for all generations in the organisation of society and the state. Constitutional texts, together with their interpretations by judges, play a significant role in determining the meaning of the constitution. The understanding of constitutional

* Fruzsina Gárdos-Orosz, PhD, acting director and senior research fellow, Institute for Legal Studies, Centre for Social Sciences, Hungarian Academy of Sciences (vršiteljica dužnosti direktorice i viša znanstvena suradnica na Institutu pravnih znanosti, Centra za društvene znanosti Mađarske akademije znanosti, e-mail: Orosz.Fruzsina@tk.mta.hu) 
provisions might change according to the requirements of time and space, while preserving prior knowledge. I argue that the normative approach requires, in accordance with the rule of law, that the decisions, justified on the basis of the constitution, be reasonably justified to the generation in which the case actually emerges. That enables the constitution, with its unamendable provisions, to provide a stable framework that is capable of adapting in order to serve the needs of future societies.

Keywords: constitutionalism, intergenerational justice, eternity clause, constitutional court

\section{The Framework Discussion}

Any discussion regarding the durability and flexibility of a constitution begins with Edmund Burke's famous concept of a constitution as an intergenerational covenant (Burke, 1955). The problem is also present in Thomas Jefferson's, James Madison's, and Thomas Paine's works related to the foundation of the United States of America (e.g. Jefferson, 1984, pp. 959-964). The problem is still present in the most recent publications in various social science disciplines, as may be seen by following the discussion in special issues of the periodical Intergenerational Justice Review.

But why do constitutions matter in view of intergenerational justice? If intergenerational justice is based on the equal rights of present and future generations, as well as on the responsibility of the present generation to preserve the environmental goods and democratic sovereignty of future generations, while providing and enforcing the rights that they might want to have in the future, then essential legal questions emerge (Tremmel, 2009). Do constitutions protect the rights or interests of future generations without becoming undue barriers; i.e., without making it impossible for future generations to exercise their sovereignty when the time comes? Constitutions can usually be amended. Amendments sometimes amount to complete revisions, but in the case of modern constitutions some parts remain stable even in those cases - those parts that provide the identity of the constitution (Rosenfeld, 2011, p. 671; Jacobsohn, 2010, p. 4). The stability of constitutions might differ, but the definition of the constitution incorporates the notion of some sort of stability, which means some sort of engagement for the future (Tushnet, 2012, pp. 226-230). 
Another question is linked to the potential role constitutional courts should play in the protection of their generation against the will of past generations codified in a constitutional text. Or are courts the guardians of earlier regulations and therefore opponents of constitutional change (Auerbach and Reinhart, 2012, pp. 17-22)? There is also debate in the literature if eternity clauses are generationally fair. The prohibition of future changes to certain provisions of a constitution take away the possibility from future generations to determine their own lives and futures (Roznai, 205, pp. 15-39).

These questions are important because constitutions seem to be intergenerational legal sources by their very nature. They are focused on serving many generations. Providing the basic institutions of government, they aim to do so for the long run; they express, usually normatively, the fundamental values of the people and place certain questions beyond the reach of simple majorities. Constitutions are usually difficult to amend precisely so that intergenerational stability and continuity may be preserved. Some of them state this explicitly in eternity clauses or other entrenchment clauses. Constitutions also wish to protect future generations from present electorates. That might be labelled paternalism if one were to suggest that future generations must be able to respond to their own problems (Beckman, 2013, pp. 775-788) in their own time. Constitutions, however, provide fundamental rights to future generations as well. On the other hand, does that not burden the sovereignty of future generations by disenfranchising them from responding to their own problems (Barry, 1978, pp. 204-248) in the fashion they deem most prudent?

Constitutions usually fulfil two tasks: one is to protect values, sometimes even by eternity clauses and by implicitly forbidding change through future amendments. The second is to entrench the rights and values the authors of the constitution believe to be important (Brown and Weiss, 2002, pp 1-5). The question is whether this is entirely just towards future generations, as people are not able to predict the future (Kavka, 1978, pp. 286-303).

The preservation of the same number of options and opportunities for action for new generations is sometimes regarded as the most important element of intergenerational justice (Brown-Weiss, 2002; Kafka, 1978; Barry, 1978). However, the notion of intergenerational justice is much more vague than this. The definition of intergenerational justice is almost impossible to agree upon, which is why it is not treated as a legal term. Rather, a philosophical and general social science approach to understanding it is favoured (Tremmel, 2015a, pp. 212-233; Tremmel, 2015b, 
125-148). The notion of intergenerational justice is often discussed with regard to questions of environmental law, because if a society wishes to provide equal options for future generations, physical and material circumstances must clearly be secured (Ekeli, 2007, pp. 378-401). However, questions related to the constitutional equality of generations need not be based on material equality, according to other approaches (Gosseries \& Meyer, 2009).

My contribution remains in the legal normative framework and aims to analyse the role of the constitution in delivering intergenerational justice. I will address the question of the role constitutional courts may play in providing a sustainable normative framework for the present and for the future. I argue that when constitutional courts are the guardians of the constitutions as interpreted by the courts, the requirement of a legal justification of all decisions will end up in a moderate, cautious approach to constitutional change. Constitutional change has its limits within the constitutional order and these limits are recognised, expressed, and observed by constitutional courts. The limits of change are settled partly in the text of the constitutions, in the eternity clauses, but in many cases by means of constitutional interpretation of the constitutional texts as well. The required stability or flexibility of the constitution is therefore provided either by the constitutional text or by the judges.

I will first argue that, according to the rules of constitutional adjudication, courts play a legitimate role in providing justice for every generation and preserving the value of intergenerational justice at the same time. Unamendability, either established by the text of the constitution or recognised by judicial constitutional adjudication, complicates this argument as it points to the limits of the interpretation competence. Hence the question remains to what extent such guarantees take away the possibility from future generations and future judges to determine their own future. I conclude that stable constitutions and, what is more, eternity (or entrenchment) clauses are fair to future generations and do not deprive them of the liberty to exercise self-determination. Constitutions could certainly be regarded as indoctrinations from the point of view of future generations, but as long as it can be argued on normative grounds that future generations are able to challenge the constitution, even its very core, I suggest that this does not hinder the sovereignty of future generations. The legal normative approach to the constitution makes this act of challenging possible, whilst on the other hand a normative order is offered for future generations as established in the constitution. Normative orders 
are undoubtedly needed to scale back the intensity of change. This is a human achievement, a value offered to future generations. They are able to adhere to it or reject it, if it is regarded only as a legal normative concept. Let me introduce my arguments with an example. We make an effort to create rules for our children. Not only is this our constitutional right but also our obligation. We are responsible for the children and we establish a legal order that allows us to decide for them and in their best interest. We interpret our rules for them and although they start reinterpreting them, it is we who decide in controversial cases. As soon as they grow up, their interpretation will be valid for their lives and they can enforce it. Our interpretation will remain subsidiary; they can take it into account according to their wishes. It will, however, be there for them, even if they are not bound by it anymore. They can opt for continuity and let our interpretation of the rules be a point of reference in their argumentation. They can conform to it or depart from it. On the other hand, they can decide to fully deny the past and create a new framework of rules. This is their decision and their parents cannot stop them.

Constitutions work in similar fashion. A constitution is by nature not only an intragenerational but an intergenerational text. Jefferson's idea of the necessity to establish a new constitution every 19 years in order to be fair to all generations is unfounded in the concept of the legal constitution (Jefferson, 1984, pp. 959-964). Constitutions in a normative sense are not enforced according to current political understanding and will. The constituent power as such is not a central element of the normative legal theories; it is not often present in legal positivism and this fact is important in understanding the function of a normative legal constitution. An autonomous legal order with the constitution as the auto-valid top norm does not have to deal with the notion of constituent power; this is left more to decisionist legal theories or outsourced to political science. This helps the paper to argue that constitutions serve the interest of intergenerational justice.

I suggest, therefore, that we remain within the framework that the normative legal concept offers for the understanding of the constitution and its unamendability, in order to give satisfactory answers to Jefferson's concerns about the rights of future generations. For legal constitutionalism, judicial constitutional adjudication is essential to observe intra- and intergenerational law understood as justice. 


\section{A Normative Approach to Understanding a Constitution}

I suggest that a certain understanding of unamendability (rigidity) belongs to the concept of legal constitutionalism, regardless of whether this is written in the text or discovered and expressed only by constitutional courts. Turning a rule-of-law democracy into an autocracy, e.g. by constitutional amendments, is not a valid legal solution in most constitutional democracies, regardless of whether their constitution contains eternity or other entrenchment clauses or not. This is because in a rule-of-law democracy, a living constitution is partly a judicial construction and in applying a legal doctrine normative requirements are found to be applicable to fundamental constitutional changes. These requirements can validly be enforced by the guardians of a legal constitution. Constitutional courts of all generations will interpret law and legal doctrine and the interaction of the applicable law; institutional safeguards and human conditionality will protect the right of future generations to self-determination within the framework of the right to self-determination of the present generation.

As András Bragyova, constitutional theorist and former judge of the Hungarian Constitutional Court explains, all constitutions - or at least some provisions of constitutions - contain values of choice. Parts of these are fundamental values that define the identity of the constitution. Parts of these values are unamendable, even if this prohibition is not incorporated explicitly in the text. They are unamendable because the source of the amending power is in the constitution and is derived from it; therefore, the pouvoir constitutent derive (the amending power) is not empowered to eliminate its essential parts (Bragyova, 2003, p. 65). "The power to amend the constitution was not intended to include the power to destroy it" (Marbury, 1919, p. 232). A revolution needs to take place before a constitution can be abolished. (Servai, 1999, p. 266).

The idea of inherent unamendability is mentioned not only in often-cited case law, but also in mainstream, well-known constitutional doctrine: "Amending the constitution must stay within the constitutional framework, this competence is based on the constitution and it cannot override it. This competence cannot involve the adoption of a new constitution..." (Schmitt, 1928, p. 16).

In modern constitutions, their stability is often guaranteed not by implicit but by explicit unamendability provisions. This is usually stated by way of eternity (Roznai, 2014, Appendix) or other entrenchment clauses (Albert, 
2010, p. 706). These provisions provide explicit obstacles to fundamental amendments to constitutions by stating, in their strictest form, that one or more provisions are unamendable. If the prohibition is final, we are referring to eternity clauses (Ewigkeitsklausel), and many jurisdictions show examples of this (the most famous amongst these is Article 79 (3) of the German Basic Law). In Europe, the constitutions of Germany, Italy, and France explicitly limit or exclude amendments of certain provisions. They do this because they have experienced the dangers that totalitarian regimes cause to the individual, society, and the state. As these constitutions usually serve as models for other European constitutions, the inclusion of an eternity clause in the constitution has become fashionable. The preventive function of such unamendability in France, Germany, and Italy, as well as in others copying them, leaves no room for doubt. This is elaborated by the German Federal Constitutional Court in its Decision BVerfGE 30, $1{ }^{1}$

The unamendability of certain parts of the constitution is firmly discussed at the level of constitutional theory as well (Roznai, 2016). Unamendable provisions on the republican form of government, on the protection of fundamental rights, or on territorial integrity give the impression of legal certainty and the inviolability of the basis of constitutional order. Romania's constitution offers good examples of all kinds of explicit unamendability. ${ }^{2}$ Albert (2013, pp. 280-281) makes a valid point that the explicit function of unamendability, which significantly affects the constitutional culture of values, remains the leading function of unamendability in practice. In reality, constitutions with eternity clauses could be disregarded or annulled completely, in the same way as constitutions without this explicit ban concerning the amendment of certain fundamental provisions.

Unamendability, explicit or implicit, in the normative framework, explains that there are core provisions in constitutions which cannot be amended, despite the will of the overwhelming majority of the people to adopt a new constitution, or without the rule of an undemocratic force that implements a new constitution. Research on implicit unamendability is also about finding this core - the unamendable part of constitutional design by way of judicial interpretation, i.e., by legal methodology. The method is further explained and applied by Roznai (2015). Judicial interpretation is

\footnotetext{
${ }^{1}$ For the function of unamendable clauses within the broader context of constitutional change, see Albert, 2009 and Roznai, 2013.

${ }^{2}$ See a complex exemplification in Jacobsohn, 2006.
} 
not used exclusively by the judiciary. All state actors and all social sciences may use legal methods.

However, the judiciary is to give the final interpretation of the text in controversial cases. The Indian Supreme Court was the first to discover implicit unamendability rooted in the basic structure of the constitution. As a consequence, the doctrine of unconstitutional constitutional amendment has spread globally and attracted promoters amongst constitutional judges of the world (Colombia, the Czech Republic, etc., are often points of reference in this discussion, see Halmai, 2015, p. 951). The Hungarian Fundamental Law of 2011, the newest constitution of the EU, does not contain provisions qualified explicitly as unamendable. ${ }^{3}$ The Hungarian Constitutional Court, however, in its decision 22/2016 (XII. 5.), declared that Hungarian constitutional identity is an inviolable core of the Fundamental Law and cannot be overruled. The identity is composed of several elements, such as the protection of fundamental rights, the protection of human dignity, respect for the historic constitution, and the sovereignty of the state.

The duration and rigidity of a constitution cannot be explained without taking a stand on how the constitution is understood. This is the first step to finding out which understanding of the constitution could better serve the interest of future generations. I believe that the role of the constitution in providing intergenerational justice is often mistreated, as authors traditionally treat the constitution as a social fact (Jefferson, 1984). I suggest that the constitution be understood as the supreme law that defines the validity of all the norms of the legal system, including the constitution (Kelsen, 1967, pp. 35-50). ${ }^{4}$ Although adopting a constitution (the constitutional moment) is undoubtedly a political act (Tóth and Lánczi, 2012, pp. 30-32), the liberal concept of constitutional democracy is based on legal constitutionalism. ${ }^{5}$ In this Kelsenian concept, a constitution contains legal norms at the top of a legal system, which legally define the validity of the legal system. This approach could be anticipated as a new level of constitutional development, where a limited government and the protection of fundamental rights are central values.

${ }^{3}$ I examine the Hungarian case in Gárdos-Orosz, 2017. Parts of my argumentation in this section are based on this text.

${ }^{4}$ The Austrian-German heritage of public law has had a very strong effect on many central European countries as well (Boulanger, 2006; Halmai, 2007).

${ }^{5}$ On the basic differences between the concepts of legal and political constitution and constitutionalism, see Bellamy, 2001 
The strength of the review power of constitutional courts and the activism of lawyers forming a judicial body are also widely accepted by both political elites and legal scholars in this system, because, according to this concept, the constitution can only be part of a normative order if it is interpreted and enforced by the state through constitutional adjudication. Amendments to a constitution are also parts of this socially constructed normative order (von Wright, 1963, p. 16; p. 189). As the normative order is always a social construction, it is per se not capable of working against the people. The incorporation of society into the constitution leaves room for the adaptation of the constitution by interpretation. The adaptation is guided by the institutions and the people of an actual living society. This concept does not recognise the conflict between present and future generations because the law is made continuous by its application and interpretation.

A constitution as a special norm contains provisions on the possibility of and limitations to its own amendment. ${ }^{6}$ These provisions are very special and the creator of these rules - the constituent power - ceases to exist at the very moment of the adoption of a constitution (Beud, 1994, p. 455). Therefore, one cannot talk about generations in one constitution. In agreement with Ross, one can suppose that the final source of law is in the constitutional system itself (Ross, 1929, p. 309). Similarly, the source of the legitimacy of a constitutional state lies neither with the people nor with the constituted state, but rather in a balanced relation between the normative order, as the ideal of constitutionalism, and governmental action (Loughlin, 2014, p. 222). We, the people, keep questioning if the established normative order is still valid, but on the other hand we generally trust this achievement.

In modern constitutions, it is usually either the people or the nation who are entitled to be the source of power (a double formula is found in both the French and Spanish constitution (Art. 3. ill. 1. (2).)), but whichever the source, the constitution normatively defines it as such. This is again a phenomenon that explains the theoretical impossibility of separating and defining different generations within the framework of this normative concept. Without a normative constitution we cannot identify the source of state power and the limits of government, nor are we capable of describing the limits of constitutional stability or change. The normative nature of the

\footnotetext{
6 This opinion is affirmed by the Constitutional Court in its decision on a referendum on the constitutional amendment 25/1999. (Decision VII. 7. CC, ABH, 1999, 251, 261).
} 
constitution implies that the rules on amending the constitution and the limits thereof are open to interpretation. This work is done by all state institutions, but with final force by separate and independent courts.

Popular sovereignty itself is a highly debated concept in modern constitutional thought and is definitely very far from empowering a concrete group of people (Jakab, 2016, pp. 92-99). Therefore, the constitution itself creates a normative ground for the will of the people in order for the constitution to gain legitimacy, but this reference applies to all people as an abstract category and is not capable of recognising or hindering generations.

\section{The Role of Constitutional Adjudication: How Do Constitutional Courts Serve Intergenerational Justice?}

The 2014 decision of the Czech Constitutional Court on striking down the constitutional amendment on the new election of the House of Representatives was heavily criticised, because the content of unamendability that it referred to was undefined and open to interpretation, thus allowing judicial interpretation to define constitutional violations on a case-by-case basis (Roznai, 2014; Preuss, 2016). Is this wide margin for interpretation necessarily problematic in the decision or, rather, does this case show how constitutional courts are able to meet the challenges of the day by interpreting an constitutional text adopted in an earlier period? I believe this case shows that it is a legitimate and reasoned decision of the courts to understand how rigid constitutions are and when it is justified to change the understanding of a provision.

Dealing with the adjudication of constitutional amendments, the Hungarian Constitutional Court developed the coherent interpretation doctrine, similar to the Indian basic structure doctrine, or the constitutional identity arguments mentioned above. Constitutions cannot say precisely in advance and in abstracto what will turn out to be unconstitutional in a future case. This phenomenon is definitely in favour of the flexibility of a constitutional text. The constitution applies for the moment. Even the most detailed constitutions are incapable of determining the exact outcome of a future case. The liberal democratic constitution declares the nature of constitutionalism, the fight against arbitrariness, against state capture, and against undue influence by courts; however, it empowers judicial interpretation to set limits in specific future cases through the application of 
the constitutional text. The concept of the normative constitution believes in institutions, structures, and concepts such as communication, balance, cooperation, negotiated values, and structured procedures. Legal interpretation by the constitutional courts or by other judicial bodies enforcing the constitution is regarded, therefore, as yet another procedure to secure justice in a constitutional democracy (Rawls, 1996, p. 239). As such, it is in line with the original purpose of modern legal interpretation (Tóth, 2015).

Within the concept of legal constitutionalism, when the constitution is part of the normative order, constitutional adjudication is perceived as a special pillar of constitutional construction. Without judicial review the constitution can be amended unlawfully without consequences; therefore, the entire normative construction collapses. Without interpretation it is not possible to define what the law is, while interpretation makes it possible for all generations to have their constitutional justice based on the same constitution. This normative approach makes it possible for future generations to validate their own interpretation of the constitution by constitutional adjudication, because constitutional judges must give justified reasons for the very generation of the case by the rule of law. Even if we have theoretical and actual disputes over who should be the final interpreter of the constitution, for the sake of our normative argumentation, it is reasonable to say that, for intergenerational justice, constitutional courts or supreme courts are rightly empowered to discover and define the meaning of constitutional provisions.

The entire constitutional construction, however, retains at least one pillar, one unamendable rule of the equal human dignity of the person. Constitutional courts make sure that this pillar remains stable and invalidates all acts of amendment that try to eliminate it. They remain the guardians of the constitution, as the constitution and the constitutional court attached to it will not eliminate themselves. The claim on intergenerational justice is also embedded in this concept of the modern democratic constitution. Once it is established, constitutional review as such is undeletable as well, according to this idea of legal constitutionalism. Once a constitution implements constitutional review, in case of conflict, the instrument of constitutional review is of ultimate necessity to say if a piece of law is contradictory to the constitution or not. There is no validity without a potential review. It is necessary to accept, based on pure logic, that constitutional review as such cannot, accordingly, be validly eliminated from the constitutional order. And this is what might serve - following the above argumentation - intergenerational justice. 


\section{Intergenerational Fairness of the Stability of a Normative Constitution}

Many argue that the Ewigkeitsklausel or implicit unamendability as judicial discovery is not eternal, because law as a social construct cannot be eternal per definitionem, and the constituent power therefore cannot burden future generations (Bentham 1843, p. 403). What is more, as Ackerman (1998) points out, constitutions sometimes change independently of changes to their text, and these changes are sometimes more significant than the formal amendments. What is then the relevance of my discussion on the normative constitution?

Constructing formal or informal unamendability as the essential feature of normative constitutionalism means that, within one constitutional system, it is not possible to amend the constitution either by constitutional amendment or by interpretation, by denying the nature of that very constitutional democracy (Albert, 2015, pp. 146-150). The validity of a formal amendment or the validity of a constitutional interpretation is a normative issue in a rule-of-law democracy. I have argued that normativity in this sense means that previously agreed and settled legal rules apply both to constitutional amendments and to their judicial interpretation. It does not give a formal definition of the content, but rather a formal definition of certain rules regarding basic values such as equal human dignity, institutions such as the constitutional court, and procedures such as constitutional review.

Unamendable norms are unamendable only in a legal sense; their normative status belongs to a given constitutional order created by society to ensure stability, democracy and freedom, limited government, and fundamental rights protection for the present and the future. I argue about intergenerational justice in this framework. A given constitutional order comes to its end if its unamendable norms disperse. As a result, a new order is created. The normative approach does not exclude the possibility of creating a new order (Körössényi, 2015), even if it does not reflect on this, because that is beyond its aims. The complexity of self-determination of future generations remains possible, because in the case of a complete rejection of the former system people of all generations have the right to step out of the normative system.

In Hungarian legal literature, it is András Bragyova who formulated the most convincing arguments that justify the unamendability of certain provisions of the former Hungarian Constitution and the Hungarian Fun- 
damental Law, and explain the relevance of this question from the point of view of European integration. He expressed this view not only in legal scholarship, but in his concurring and dissenting opinions in constitutional court case law as a former judge.

He explains that all members of the European Union should know the limits of the amendability of their own constitutions, because intense disputes have arisen across Europe with regard to the limits of the transfer of state sovereignty to the European Union. The absolute limits of such transfers lie in unamendable norms or in the otherwise defined unamendability of the constitutions of the member states. Pure political consensus, for example, cannot consent to certain EU developments if they are in contradiction with the unamendable parts of a constitution (Bragyova, 2003, p. 76).

Normative constitutional orders undoubtedly scale back the number of possibilities for change by providing a clear legal framework. All generations have the chance, however, to challenge the "indoctrination" of this framework, because law as a social construct is limited in nature and open to change. The normative construction of judicial constitutional interpretation is a balanced instrument to finding the balance between preservation and adaptation. I believe, therefore, that it is fair to give constitutions to future generations according to this normative legal approach.

\section{Conclusion}

I have argued that constitutions serve intergenerational justice on the basis of two observations. One is that it becomes difficult to interpret correctly the limiting, binding nature of the constitution and of the eternal or entrenched rules, if we forget about the legal-normative concept that made these ideas of strong constitutionalism and unamendability popular. The popularity of adopting a constitution and unamendable rules saw renewed enthusiasm worldwide after the Second World War. These constitutions were adopted or imposed in order to serve mostly as Grundnorms, in a Kelsenian sense. Bearing in mind discussions in the fields of law, legal theory, and political philosophy, I have argued that the wellknown normative approach helps to offer satisfactory answers to concerns related to the promotion of intergenerational justice. It contains a degree of unamendability in all cases, which ensures stability, but on the other hand, due to the limited concept, it allows for complete change by stepping aside and adopting a new constitution. 
My second argument was that the normative approach serves the best interest of future generations, because it requires the implementation of constitutional adjudication. That makes the stable system flexible enough to serve the needs of all generations. Constitutional courts are charged with finding a justifiable and reasoned interpretation of the day, and they have the legitimacy and the capacity to meet this challenge. The judge adjudicating the case is a member of the generation that belongs to the case, and her task is to justify her choice for her generation and by the chosen interpretative methods within the framework of the already settled legal knowledge.

The constitution as a normative concept does not recognise different generations, but rather presupposes and safeguards the continuity of law. By allowing the flexible adaptation of the interpreted rules, while providing stability, it still leaves equal room for change for all generations.

\section{References}

Ackerman, B. (1998). We the people, Volume 2: Transformations. Cambridge, MA: Harvard University Press.

Albert, R. (2017). Constitutions as handcuffs. Intergenerational Justice Review, 10(1) 18-30.

Auerbach, B., \& Reinhart, M. (2012). Antonin Scalia's constitutional textualism: The problem of justice to posterity. Intergenerational Justice Review, 12(1), $17-22$.

Barry, B. (1978). Circumstances of intergenerational justice. In. R. Sikora \& B. Barry (Eds.), Obligations to future generations (pp. 204-248). Philadelphia, PA: Temple University Press.

Brown-Weiss, E. (2002). Intergenerational fairness and rights of future generations. Intergenerational Justice, 2(3), 1-5.

Beaud, O. (1994). La puissance de l'etat [The power of the state], Paris, France: PUF.

Bellamy, R. (2007). Political constitutionalism: A republican defence of the constitutionality of democracy, Cambridge, MA: Cambridge University Press.

Bentham, J. (1843). The book of fallacies. In J. Bowring (Ed.), The works of Jeremy Bentham (Vol. 2). (pp. 379-467) Edinburgh, Scotland: William Tait.

Beckman, L. (2013). Democracy and future generations: Should the unborn have a voice? In: J.-Ch. Merle, (Ed.), Spheres of global justice Volume 2, Fair distribution: Global economic, social and intergenerational justice (pp. 775-788). Dordrecht, Netherlands: Springer.

Boulanger, C. (2006). Europeanisation through judicial activism: The Hungarian Constitutional Court's legitimacy and the return to Europe. In W. Sadurski, 
A. Czarnota \& M. Krygier (Eds.), Spreading democracy and the rule of law? (pp. 263-280) Dordrecht, Netherlands: Springer.

Bragyova, A. (2003). Vannak-e megváltoztathatatlan normák az alkotmányban? [Are there unamendable norms in the constitution?]. In A. Bragyova (Ed.), Holló András 60. születésnapjára (Melange to the birtbday 60 of András Holló) (pp. 65-88). Miskolc, Hungary: Bíbor Kiadó.

Burke, E. (1955). Reflections on the revolution in France. New York, NY: Bobbs-Merrill.

Ekeli, K. S. (2007). Green constitutionalism: The constitutional protection of future generations. Ratio Juris, 20(3), 378-401.

Gosseries, A., \& Meyer, L. H. (Eds.) (2009). Intergenerational justice. Oxford, United Kingdom: Oxford University Press.

Gárdos-Orosz, F. (in press). Unamendability as a judicial discovery? In R. Albert \& Y. Roznai (Eds.). Unamendability. Dordrecht, Netherlands: Springer. Forthcoming.

Halmai, G. (2007). The transformation of Hungarian constitutional law from 1985 to 2005. In A Jakab, P Takács \& A. F. Tatham (Eds.) The transformation of the Hungarian legal order 1985-2005. (pp. 547-561) The Hague, Netherlands: Kluwer Law International.

Jacobsohn, G. J. (2006). An unconstitutional constitution? A Comparative Perspective. International Journal of Constitutional Law, 4(3), 460-487.

Jacobsohn, G. J. (2010). Constitutional identity. Cambridge, MA: Harvard University Press.

Jakab, A. (2016). European constitutional language. Cambridge, UK: Cambridge University Press.

Jefferson, T. (1984). Letter to James Madison, 6 September 1789. In M. D. Peterson (Ed.). Thomas Jefferson: Writings (pp. 959-964). New York, NY: Library of America.

Kavka, G. (1978): The futurity problem. In R. Sikora \& B. Barry (Eds.). Obligations to future generations (pp. 286-203). Philadelphia, PA: Temple University Press.

Konstantin, C. (2017). Constitutions as chains? On the intergenerational challenges of constitution-making. Intergenerational Justice Review, 10(1), 32-41.

Körösényi, A. (2015). A magyar demokrácia három szakasza és az Orbán-rezsim [Three periods of the Hungarian democracy: The Orbán regime] in A. Körösényi (Ed.), A magyar politikai rendszer - negyedszázad után (The Hungarian political system - after 25 years) (pp. 401-422). Budapest, Hungary: Osiris.

Loughlin, M. (2014). The concept of constituent power. European Journal of Political Theory, 13(2), 218-237.

Marbury, W. L. (1919). The limitations upon the amending power. Harvard Law Review, 33, 223-235.

Kelsen, H. (1967). Pure theory of law (Max Knight, Trans.). Berkeley, CA: University of California Press. 
Servai, H. \& "Homi" M. (1996). Constitutional law of India (Vol. 3) (4th ed.). New Delhi, India, Internationlal Law Publisher.

Schmitt, C. (1928). Verfassungslebre [Constitutional theory]. Munich, Germany: Duncker \& Humblot.

Preuss, O. (2016): Eternity clause as a clever instrument: Lessons from the Czech case law, Acta Juridica Hungarica: The Hungarian Journal for Legal Studies, 57(3), 289-304.

Rawls, J. (1996). Political liberalism (2nd ed.). New York, NY: Columbia University Press.

Rosenfeld, M. (2011). Constitutional identity. In M. Rosenfeld \& A. Sajó (Eds.), The Oxford handbook of comparative constitutional law (pp. 761-787). Oxford, United Kingdom: Oxford University Press.

Ross, A. (1929). Theorie der rechtsquellen [Theory of legal sources]. Leipzig, Austria: F. Deuticke.

Roznai, Y. (2016). Unconstitutional constitutional amendments. Oxford, United Kingdom: Oxford University Press.

Tóth, A. G. (2015). Hungary's constitutional transformation from a Central-European comparative perspective. In Henning Glaser (Ed.), Norms, interests, and values: Conflict and consent in the constitutional basic order (pp. 129-158). Baden-Baden, Germany: Nomos 2015.

Tóth, A.G. \& Lánczi, A. (2012). Szükség van-e írott alkotmányra? [Do we need a written constitution?]. In A. Jakab \& A. Körösényi (Eds.), Alkotmányozás Magyarországon és máshol: Politika-tudományi és alkotmányjogi megközelitések (Constitution making in Hungary and elsewhere. Approached of political science and constitutional law) (pp. 18-32). Budapest, Hungary: MTA TK Politikatudományi Intézet - Új Mandátum.

Tushnet, M. (2011). Constitution. In M. Rosenfeld \& A. Sajó (Eds.), The Oxford bandbook of comparative constitutional law (pp. 226-230) Oxford, United Kingdom: Oxford University Press.

Tremmel, J. (2009). A theory of intergenerational justice. London, United Kingdom: Earthscan.

Tremmel, J., \& Wilhelm, J. (2015a). Democracy or epistocracy? Age as a criterion of voter eligibility. In J. Tremmel, A. Mason, I. Dimitrijoski \& P. Godli (Eds.), Youth quotas and other efficient forms of youth participation in ageing societies (pp. 125-148). Dordrecht, Netherlands: Springer.

Tremmel, J (2015b): Parliaments and future generations: The four-power model. In: Birnbacher, D. Thorseth, M. (Eds.) The Politics of sustainability: Philosophical perspectives (pp. 212-133). London, United Kingdom: Routledge.

von Wright, G. H. (1963). Norm and action. London, United Kingdom: Routledge $\&$ Kegan Paul.

Vörös, I. (2014). Hungary's constitutional evolution during the last 25 years. Südosteuropa: Journal for Politics and Society, 63(2), 173-200. 


\section{THE STABILITY OF CONSTITUTIONS AND THEIR ROLE IN PROMOTING INTERGENERATIONAL JUSTICE}

\section{Summary}

This article argues that the legal normative concept of the constitution, with its inherent stability, does not binder, but instead serves intergenerational justice. The author bas two main observations. One is that unamendability belongs to the nature of the constitution no matter if this is specified in the constitution as an eternity clause or not. Even constitutions that do not contain eternity or other entrenchment clauses are not completely flexible, as this is the nature of the constitution. The strength of the stability in the normative sense depends partly on the jurisprudence of the constitutional court. The author argues that this a key element to prove that constitutions are able to serve intergenerational justice. The second argument that follows from the first one is that if constitutional courts play this role in interpreting the constitution, future judges can always adapt the constitution to the understanding of the law according to future generations. However, this argument is valid only if we accept that constitutionality is a normative concept and the level of abstraction of the constitution belps to preserve the competences of future generations. The popularity of adopting a constitution and unamendable rules saw renewed enthusiasm globally after the Second World War. Ensuring stability on the other hand yields solid ground to build on for new interpretations, but due to the limited concept embedded in the normative world, it allows for complete change as well, by stepping aside and adopting a new constitution. Therefore, the normative approach serves the best interest of future generations by requiring the implementation of constitutional adjudication. The constitution as a normative concept does not recognise different generations, even if it is intragenerational and intergenerational, but rather presupposes and safeguards the continuity of the law. By allowing the flexible adaptation of the interpreted rules, while providing stability, it leaves equal room for change for all generations.

Keywords: constitutionalism, intergenerational justice, eternity clause, constitutional court 


\title{
STABILNOST USTAVA I NJEGOVA ULOGA U PROMICANJU MEĐUGENERACIJSKE PRAVEDNOSTI
}

\begin{abstract}
Sažetak
U radu se zastupa tvrdnja da prirodna stabilnost normativnog ustava omogućava, tj. ne priječi, medugeneracijsku pravednost. U radu se navode dva glavna zapažanja. Prvo glasi da je nepromjenjivost prirodno obilježje ustava čak $i$ kada on ne sadržava klauzulu vječnosti te tako ni ustav koji ne sadržava klauzulu vječnosti ili neku drugu klauzulu ukorijenjenosti nije u potpunosti fleksibilan. Razina stabilnosti u normativnom smislu dijelom ovisi o ustavnome sudu. Prema autorici, to je ključni dokaz da ustav može omogućiti medugeneracijsku pravednost. Iz prvoga slijedi drugo zapažanje: ako je takva uloga ustavnog suda u tumačenju ustava, ustavni će suci uvijek moći prilagoditi ustav ovisno o tome kako će buduće generacije tumačiti zakone. No taj je argument valjan jedino ako ustavnost pribvaćamo kao normativnu. Popularnost usvajanja ustava i nepromjenjivib pravila iznova je porasla na globalnoj razini nakon Drugoga svjetskog rata. Stabilnost pruža solidan temelj za nova tumačenja, no sobzirom na ograničenja koja nameće normativnost također dopušta i temeljnu promjenu u smislu usvajanja novoga ustava. Stoga je normativan pristup u najboljem interesu budućib generacija jer zabtijeva primjenu ustavnog sudovanja. Normativni ustav ne čini razliku među generacijama, bez obzira na to što je unutargeneracijski $i$ međugeneracijski, već štiti zakonski kontinuitet. Time što omogućava fleksibilnu prilagodbu protumačenih pravila istovremeno osigurava stabilnost i svim generacijama nudi jednaku mogućnost za promjene.

Ključne riječi: ustavnost, međugeneracijska pravednost, klauzula vječnosti, ustarni sud
\end{abstract}

